\title{
Adsorption Characteristics of Copper (II) onto Ferrocene Modified Resin
}

\author{
Qian Wang, Senlin Tian, Zongliang He, Jiaqi Li, and Ping Ning
}

\begin{abstract}
Ferrocene (Fc) modified cation exchange resin (FMCER) was synthesized for copper adsorption process and characterized by XRF and BET analysis. Fc has been successfully impregnated into resin, and Fc loaded on resin was about $0.1792 \%(w / w)$. Both surface area and pore width of resin was enlarged. Results from batch experiments indicated that the adsorption kinetics of $\mathrm{Cu}^{2+}$ obeyed pseudo-second-order kinetic model and the adsorption rate constant was $0.0011 \mathrm{~g} / \mathrm{mg} / \mathrm{min}$. Langmuir adsorption isotherm model fitted the adsorption of $\mathrm{Cu}^{2+}$ well. The adsorption process of $\mathrm{Cu}^{2+}$ was exothermic reaction. The adsorption process was $\mathrm{pH}$ dependent and the optimal $\mathrm{pH}$ was found to be 4-5, and maximum removal efficiency was $38.59 \%$ at $\mathbf{p H} 4$.
\end{abstract}

Index Terms-Ferrocene modified cation exchange resin, $\mathrm{Cu}^{2+}$, adsorption kinetics, isotherm study.

\section{INTRODUCTION}

Water pollution has been attended for several decades, especially heavy metals pollution. Accumulation of heavy metals in living tissues through food chain has already poses serious health problems [1]-[3]. Copper pollution is common to see in southwest china, it is usually arises from copper mining and smelting, brass manufacture [4], et al. Wastewater containing copper from industries can not be discharged directly before treatment, and the removal and recovery of copper from wastewater is important in the protection of the environment and human health.

Adsorption, biosorption, complexation, chemical precipitation, solvent extraction, ion exchange and membrane processes have been commonly used in heavy metal contained wastewater treatment [5]-[6]. Adsorption is a high efficient and economical method in heavy metal removal from aqueous solutions among all the processes mentioned above [7]. Resin has attracted considerable attention for several years, because of its wide applications in environmental pollution remediation such as the removal of organic or inorganic pollutants from wastewater [8]-[10]. Resin is considered to be economic, and has already been successfully used in recovery of precious metals [11]-[13], such as $\mathrm{Au}, \mathrm{Ag}, \mathrm{Cu}, \mathrm{Cr}$, etc. Fatal drawbacks such as small $\mathrm{pH}$ window in the range of 1-1.4 and limitation of surface area and pore width are there, thus, adsorption capacity was not high for heavy metals.

To overcome drawbacks mentioned above, in this study, cation exchange resin was modified with ferrocene $(\mathrm{Fc})$ and

Manuscript received November 14, 2012; revised January 13, 2013.

The authors are with Kunming university of Science and Technology, Yunnan, China (email: drifting leaf@126.com). used in copper (II) adsorption. Fc was a kind of organic transition metallic compound, which is considered to have donor-acceptor conjugated structure and rigid skeleton [14]-[16], and the impregnation of Fc may change surface characteristics of cation exchange resin and improve the adsorption capacity. Effects of initial solution $\mathrm{pH}$ and contact time on adsorption capacity were investigated. The adsorption isotherms and kinetics of the adsorbent were measured, and equilibrium data were fitted to Langmuir, Freundlich equations to determine the correlation between the isotherm models and experimental data.

\section{MATERIALS AND METHODS}

Cation exchange resin was rinsed by acids to remove the mechanical impurities as pretreatment. A given amount of FeCp was dissolved in alcohol, and the pretreated resin was added into the FeCp solution, shaken for $5 \mathrm{~h}$. The clear supernatant was discarded, and the final FeCp modified resin was washed several times with alcohol to remove redundant $\mathrm{FeCp}$. The sample was dried at $70^{\circ} \mathrm{C}$ and kept in a sealed bottle. Cation exchange resin modified with ferrocene was investigated by XRF and $\mathrm{N}_{2}$ adsorption-desorption analysis. The $\mathrm{Cu}^{2+}$ adsorption data from water solutions were obtained by the immersion method. The adsorption experiments were carried out by agitating $0.25 \mathrm{~g}$ adsorbent in $250 \mathrm{~mL} \mathrm{Cu}^{2+}$ solution having concentrations ranging from 0 $\mathrm{mg} / \mathrm{L}$ to $640 \mathrm{mg} / \mathrm{L}$ with the $\mathrm{pH}$ of $2-7$ and the temperatures $\left(30^{\circ} \mathrm{C}, 40^{\circ} \mathrm{C}, 50^{\circ} \mathrm{C}\right)$. The solution and solid phase were separated by filtration, and the $\mathrm{Cu}^{2+}$ solutions were analyzed using a atomic absorption spectrophotometer (Shimadzu AA6300C). The $\mathrm{Cu}^{2+}$ adsorption capacity at equilibrium, $Q_{e}(\mathrm{mg} / \mathrm{g})$, can be calculated from:

$$
Q_{\mathrm{e}}=\frac{V\left(C_{0}-C_{e}\right)}{m}
$$

where $C_{o}(\mathrm{mg} / \mathrm{L})$ is the initial $\mathrm{Cu}^{2+}$ concentration in liquid phase, $C_{e}(\mathrm{mg} / \mathrm{L})$ denotes the $\mathrm{Cu}^{2+}$ concentration in liquid phase at equilibrium, $\mathrm{V}(\mathrm{L})$ represents the total volume of the $\mathrm{Cu}^{2+}$ solution, and $\mathrm{m}(\mathrm{g})$ is the mass of the adsorbent.

\section{RESULTS AND DISCUSSION}

\section{A. Characterization of FMCER}

Cation exchange resin and FMCER were dried at $40^{\circ} \mathrm{C}$ and detected using X-Ray Fluorescence (XRF). The components of main elements of both cation exchange resin and FMCER are shown in Table I. As depicted in Table I, 
the ratio of Fe contained in FMCER was much higher than that in untreated resin, the ratio of $\mathrm{Fe}$ incorporate to resin was about $0.0037 \%$, the ratio increased to $0.0580 \%$ after modification by $\mathrm{Fc}$, and the ratio of $\mathrm{Fc}$ was calculated to be $0.1792 \%$.

The surface and pore characteristics of untreated resin and FMCER were determined using $\mathrm{N}_{2}$ adsorption-desorption analysis, and the results were depicted in Table II. The surface area of untreated resin was about $1.7 \mathrm{~m}^{2} / \mathrm{g}$, while FMCER was $2.4 \mathrm{~m}^{2} / \mathrm{g}$. Pore diameter of cation exchange resin was enlarged from $2.07 \mathrm{~nm}$ to 5.38 $\mathrm{nm}$ through the impregnation of Fc.

TABLE I: SQX CALCULATED RESULTS OF UNTREATED RESIN AND FMCER

\begin{tabular}{ccc}
\multicolumn{3}{c}{$($ MASs: \%) } \\
\hline \hline Component & Untreated resin & FMCER \\
\hline $\mathrm{C}$ & 97.5416 & 96.0021 \\
$\mathrm{~S}$ & 1.2748 & 2.7353 \\
$\mathrm{O}$ & 0.6385 & 0.6457 \\
$\mathrm{Na}$ & 0.3668 & 0.4862 \\
$\mathrm{Fe}$ & 0.0037 & 0.0580 \\
\hline \hline
\end{tabular}

TABLE II: FMCER CHARACTERIZATION DATA

\begin{tabular}{ccc}
\hline \hline & Untreated resin & FMCER \\
\hline BET surface $\left(\mathrm{m}^{2} / \mathrm{g}\right)$ & 1.7 & 2.4 \\
$\mathrm{~V}_{\text {total }}\left(\mathrm{cm}^{3} / \mathrm{g}\right)$ & 10.00 & 11.73 \\
$\mathrm{~S}_{\mathrm{BJH}}\left(\mathrm{m}^{2} / \mathrm{g}\right)$ & 1.6 & 1.7 \\
$\mathrm{~V}_{\mathrm{BJH}}\left(\mathrm{cm}^{3} / \mathrm{g}\right)$ & 0.0020 & 0.0023 \\
Pore diameter BJH $(\mathrm{nm})$ & 2.07 & 5.38 \\
Fe content $(\%)$ & $0.0037 \%$ & $0.0580 \%$ \\
\hline \hline
\end{tabular}

\section{B. Kinetic Study}

The kinetic study for the adsorption of $\mathrm{Cu}^{2+}$ was conducted at $\mathrm{pH}$ 3. $0.25 \mathrm{~g} / \mathrm{L}$ adsorbent was added into 250 $\mathrm{mL} 640 \mathrm{mg} / \mathrm{L} \mathrm{CuSO}_{4}$ solution, Samples were taken at time intervals of $0.5,1.0,1.5,2.0,2.5,3.0,3.5,4.0,4.5,5.0,5.5$, 6.0, 6.5 and $7.0 \mathrm{~h}$. The adsorption of $\mathrm{Cu}^{2+}$ onto FMCER was time dependent and the equilibrium time required for maximum removal of $\mathrm{Cu}^{2+}$ was about $6 \mathrm{~h}$. The adsorption capacity of FMCER for $\mathrm{Cu}^{2+}$ was $218 \mathrm{mg} / \mathrm{g}$, as shown in Fig.1.

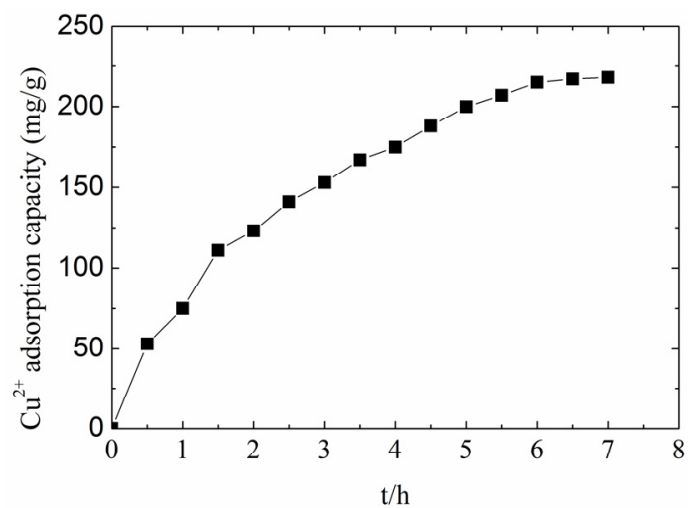

Fig. 1. Adsorption of copper (II) onto FMCER and kept shaking at $30^{\circ} \mathrm{C}$.

To describe the kinetic behavior of the adsorption process, pseudo-first-order and pseudo-second-order equations depicted in $\mathrm{Eq}(2)-(3)$ were used to analyze the experiment data.

$$
\begin{gathered}
\lg \left(q_{e}-q_{t}\right)=\lg q_{e}-\frac{k_{1}}{2.303} t \\
\frac{\mathrm{t}}{\mathrm{q}_{\mathrm{t}}}=\frac{1}{k_{2} q_{e}^{2}}+\frac{1}{q_{e}} t
\end{gathered}
$$

where $q_{e}$ and $q_{t}(\mathrm{mg} / \mathrm{g})$ are the amount of $\mathrm{Cu}^{2+}$ adsorbed at the equilibrium time and time $\mathrm{t}(\mathrm{h})$, respectively. $\mathrm{k}_{1}\left(\mathrm{~min}^{-1}\right)$, $\mathrm{k}_{2}\left(\mathrm{~g} \cdot \mathrm{mg}^{-1} \cdot \mathrm{min}^{-1}\right)$ are the rate constants of adsorption of the pseudo-first-order equation and pseudo-second-order equation, respectively. Fig. 2 shows the linearized form of the pseudo-first-order and pseudo-second-order models for $\mathrm{Cu}^{2+}$ adsorption on FMCER. The pseudo-first-order rate constants $\mathrm{k}_{1}, \mathrm{q}_{\mathrm{e}}$ and pseudo-second-order rate constants $\mathrm{k}_{2}$, $\mathrm{q}_{\mathrm{e}}$ for $\mathrm{Cu}^{2+}$ were calculated from the slope and intercept of the linear plots of $\log \left(\mathrm{q}_{\mathrm{e}}-\mathrm{q}_{\mathrm{t}}\right)$ versus $\mathrm{t}$ and $\mathrm{t} / \mathrm{q}_{\mathrm{t}}$ versus $\mathrm{t}$, and the results were summarized in Table III.

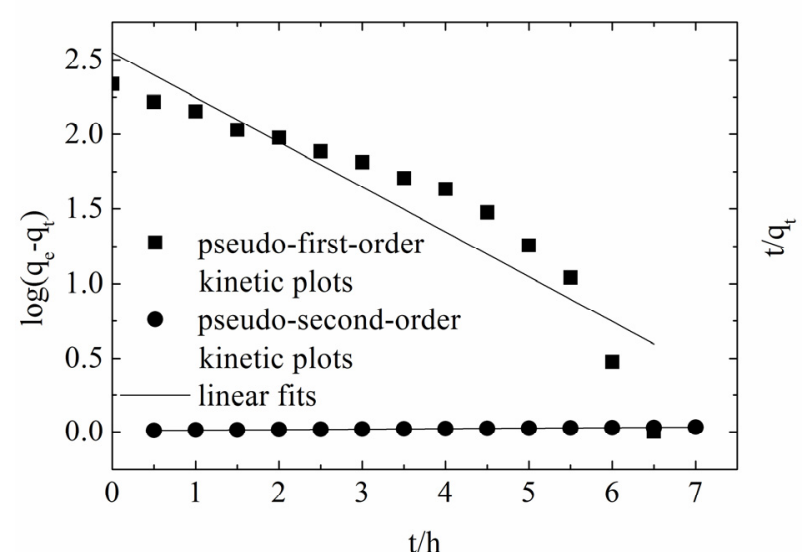

Fig. 2. Kinetic study of adsorption $\mathrm{Cu}^{2+}$ onto FMCER (initial concentration of $\mathrm{Cu}^{2+} 640 \mathrm{~g} / \mathrm{L}, \mathrm{FMCER} 1 \mathrm{~g} / \mathrm{L}, \mathrm{pH}=3,30^{\circ} \mathrm{C}$ )

\begin{tabular}{|c|c|c|c|c|c|c|}
\hline $\begin{array}{l}\text { sam } \\
\text { ple }\end{array}$ & \multicolumn{3}{|c|}{ Pseudo-first-order equation } & \multicolumn{3}{|c|}{$\begin{array}{c}\text { Pseudo-second-order } \\
\text { equation }\end{array}$} \\
\hline & $\mathrm{k}_{1}\left(\min ^{-1}\right)$ & $\mathrm{q}_{\mathrm{e}}(\mathrm{mg} / \mathrm{g})$ & $\mathrm{R}^{2}$ & $\begin{array}{c}\mathrm{k}_{2}(\mathrm{~g} / \mathrm{mg} \\
/ \mathrm{min})\end{array}$ & $\begin{array}{c}\mathrm{q}_{\mathrm{e}}(\mathrm{mg} \\
/ \mathrm{g})\end{array}$ & $\mathrm{R}^{2}$ \\
\hline $\mathrm{Cu}^{2+}$ & 0.6920 & 353.6959 & 0.8610 & 0.0011 & 231.4 & 0.9908 \\
\hline
\end{tabular}

TABLE III: KINETIC PARAMETERS FOR $\mathrm{CU}^{2+}$ ADSORPTION ONTO FMCER

The coefficients $\mathrm{R}^{2}$ for the pseudo-first-order model was only 0.8610 , and the theoretical values of $\mathrm{q}_{\mathrm{e}}$ deviated from experiment data obviously. For the pseudo-second-order kinetic model, the correlation coefficients were 0.9908 and the theoretical $\mathrm{q}_{\mathrm{e}}$ was $231.4 \mathrm{~g}$, which agreed well with the experimental $\mathrm{q}_{\mathrm{e}}$ in comparison. The results indicated that the pseudo-second-order model could adequately describe the adsorption kinetics for $\mathrm{Cu}^{2+}$.

\section{Adsorption Isotherm of FMCER}

The adsorption isotherms were established at $20^{\circ} \mathrm{C}, 30^{\circ} \mathrm{C}$ and $40^{\circ} \mathrm{C}$ by batch experiments with initial $\mathrm{Cu}^{2+}$ concentrations varying from 0 to $640 \mathrm{mg} / \mathrm{L}$ under the condition of $1 \mathrm{~g} / \mathrm{L}$ adsorbent at $\mathrm{pH} 3$. The isotherm of $\mathrm{Cu}^{2+}$ on FMCER is shown in Fig. 3. The $\mathrm{Cu}^{2+}$ adsorption capacity increased considerably with the equilibrium concentration increasing from 0 to $422 \mathrm{mg} / \mathrm{L}$. 


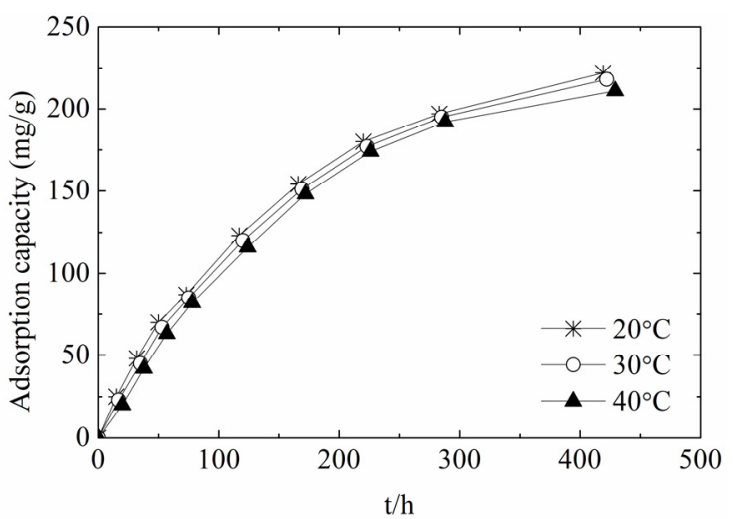

Fig. 3. adsorption isotherm of $\mathrm{Cu}^{2+}$ onto FMCER (initial $\mathrm{Cu}^{2+}$ concentration 0-640 mg/L, 250mL, FMCER $1 \mathrm{~g} / \mathrm{L}, \mathrm{pH}=3$, shaking $7 \mathrm{~h}$, temperature $20^{\circ} \mathrm{C}$, $30^{\circ} \mathrm{C}, 40^{\circ} \mathrm{C}$ )

Equilibrium adsorption data of $\mathrm{Cu}^{2+}$ onto FMCER were fitted to Langmuir, Freundlich models, and the two linear isotherm model equations were described in $\mathrm{Eq}(4)-(7)$ :

$$
q_{e}=\frac{b q_{m} c_{e}}{1+b c_{e}}
$$

The linear from the equation is:

$$
\begin{gathered}
\frac{1}{q_{e}}=\frac{1}{b q_{m}} \frac{1}{c}+\frac{1}{q_{m}} \\
q_{e}=K_{F} C_{e}^{\frac{1}{n}}
\end{gathered}
$$

The linear from the equation is:

$$
\ln q_{e}=\ln K_{F}+\frac{1}{n} \ln C_{e}
$$

where $q_{e}$ is the adsorption capacity at equilibrium $(\mathrm{mg} / \mathrm{g})$ and $C_{e}$ is the equilibrium concentration of $\mathrm{Cu}^{2+}$ in solution $(\mathrm{mg} / \mathrm{L}), \mathrm{K}_{\mathrm{F}}$ and $\mathrm{n}$ are Freundlich constants. The estimated isotherm model parameters and linear regression coefficient $\left(\mathrm{R}^{2}\right)$ values obtained are listed in Table IV.

It is obvious that, the value of $\mathrm{R}^{2}$ for adsorption of $\mathrm{Cu}^{2+}$ based on Freundlich was 0.9400 , which was much lower than 0.9990 based on Langmuir. The Langmuir isotherm model describes the adsorption data for $\mathrm{Cu}^{2+}$ much better than Freundlich. The adsorption capacity $\left(\mathrm{K}_{\mathrm{F}}\right)$ was $1639.2597 \mathrm{mg} / \mathrm{g}$ in the Freundilch equation, while the value of adsorption capacity $\left(\mathrm{q}_{\mathrm{e}}\right)$ was about $250 \mathrm{mg} / \mathrm{g}$ in Langmuir, according to which, the Langmuir constant $\mathrm{b}$ was 0.0058 .

TABLE IV: ESTIMATED ISOTHERM PARAMETERS FOR $\mathrm{CU}^{2+}$ ADSORPTION

\begin{tabular}{ccc}
\hline \multicolumn{3}{c}{ ON FMCER } \\
\hline \hline Model & parameters & Fc modified resin \\
\hline Langmuir Equation & $\mathrm{q}_{\mathrm{m}}$ & 250.00 \\
& $\mathrm{~b}$ & 0.0058 \\
Freundlich & $\mathrm{R}^{2}$ & 0.9990 \\
& $\mathrm{~K}_{\mathrm{F}}$ & 1639.26 \\
& $\mathrm{n}$ & 4.0650 \\
& $\mathrm{R}^{2}$ & 0.9400 \\
\hline \hline
\end{tabular}

The adsorption capacity obtained from Langmuir agreed much better with the data obtained experimentally.
In the Langmuir equation, the value for maximum adsorption capacity $\left(\mathrm{q}_{\mathrm{e}}\right)$ for $\mathrm{Cu}^{2+}$ adsorption onto FMCER decreased with the increasing of temperature which also shows an exothermic process in the adsorption process.

D. Effect of $\mathrm{pH}$ on $\mathrm{Cu}^{2+}$ adsorption

The effect of $\mathrm{pH}$ on $\mathrm{Cu}^{2+}$ adsorption was studied, ranging from 2 to 7, and the results were shown in Fig. 4. The results indicated that the $\mathrm{pH}$ of the aqueous solution plays a major role in determining the amount of $\mathrm{Cu}^{2+}$ adsorbed onto FMCER. The adsorption capacity of $\mathrm{Cu}^{2+}$ onto FMCER increased as the initial solution $\mathrm{pH}$ value increased, and $\mathrm{pH}$ ranging from 4 to 5 was the optimum $\mathrm{pH}$ for the adsorption process. The adsorption capacities of FMCER at $\mathrm{pH} 4,5$ were 247 and $245 \mathrm{mg} / \mathrm{g}$, respectively. The effect of $\mathrm{pH}$ may be explained in relation to the interaction of $\mathrm{Cu}^{2+}, \mathrm{Cu}(\mathrm{OH})^{+}$, and $\mathrm{Cu}(\mathrm{OH})_{2}$ with functional group $-\mathrm{HSO}_{3}$ present in surface of FMCER as follows:

$$
\begin{gathered}
-\mathrm{HSO}_{3} \rightarrow \mathrm{H}^{+}+-\mathrm{SO}^{3-} \\
\mathrm{Cu}^{2+}+-\mathrm{SO}^{3-} \rightarrow-\mathrm{SO}_{3} \mathrm{Cu}^{+} \\
-\mathrm{SO}^{3-}+\mathrm{Cu}(\mathrm{OH})^{+} \rightarrow-\mathrm{SO}_{3} \mathrm{Cu}(\mathrm{OH})
\end{gathered}
$$

It can be seen that at low $\mathrm{pH}$ values, $\mathrm{H}^{+}$competes with the $\mathrm{Cu}$ ions for the active surface sites. On the other side, less $-\mathrm{SO}_{3}$ are ionized at this range of initial solution $\mathrm{pH}$. Moreover, $\mathrm{Cu}^{2+}$ and $\mathrm{Cu}(\mathrm{OH})^{+}$are the dominant species involved in adsorption process below $\mathrm{pH} 5$, and $\mathrm{Cu}(\mathrm{OH})_{2}$ was the leading at $\mathrm{pH}$ values higher than 6 , thus, the removal of $\mathrm{Cu}^{2+}$ was not only attributed to the adsorption process, but also the precipitation at neutral condition.

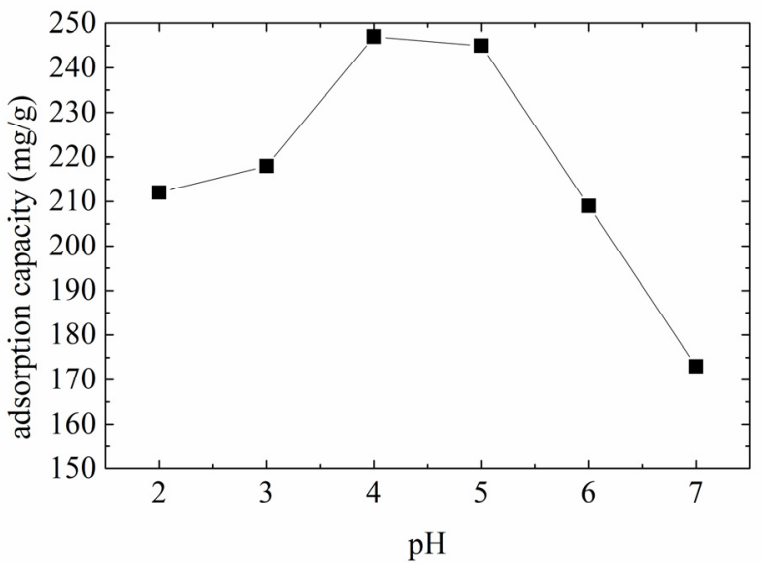

Fig. 4. Effect of $\mathrm{pH}$ on $\mathrm{Cu}^{2+}$ adsorption by FMCER $\left(\mathrm{Cu}^{2+}\right.$ initial concentration $640 \mathrm{mg} / \mathrm{L}, 250 \mathrm{~mL}$, FMCER $1 \mathrm{~g} / \mathrm{L}$, temperature $30^{\circ} \mathrm{C}$ )

\section{CONCLUSION}

Ferrocene modified cation exchange resin was prepared using immersion method, and used in $\mathrm{Cu}^{2+}$ adsorption process. Fc was successfully loaded onto cation exchange resin, pore width and surface area of the resin was enlarged, and the ratio of $\mathrm{Fc}$ on resin $(\mathrm{w} / \mathrm{w})$ was $0.1792 \%$. The $\mathrm{Cu}^{2+}$ adsorption process obeyed pseudo-second-order kinetic model. The adsorption of $\mathrm{Cu}^{2+}$ followed the Langmuir adsorption isotherm model and the adsorption process was an exothermic reaction. The adsorption of $\mathrm{Cu}^{2+}$ was found to be $\mathrm{pH}$ dependent and the optimal $\mathrm{pH}$ was found to be 4-5. 


\section{REFERENCE}

[1] G. Bayramoglu and M. Y. Arica, "Adsorption of Cr (IV) onto PEI immobilized acrylate-based magnetic beads: isotherm, kinetics and thermodynamics study," Chem. Eng. J., vol. 139, pp. 20-28, 2008.

[2] A. Smith, C. Hopenhayn-Rich, M. Bates, H. Goeden, I. Herta-Picciotto, H. Duggan et al. "Cancer risks from zrsenic in drinking water," Environ. Health. Persp., vol. 97, pp. 259-267, 1992.

[3] J. Gregor, "Arsenic removal during conventional aluminium-based drinking-water treatment," Water Research, vol. 35, no. 7, pp. 1659-1664, 2001.

[4] X. J. Wang, X. Liang, Y. Wang, X. Wang, M. Liu, D.Q. Yin et al. "Adsorption of copper(II) onto activated carbons from sewage sludge by microwave-induced phosphoric acid and zinc chloride activation," Desalination, vol. 278, no. 1-3, pp. 231-237, 2011.

[5] T. Suzuki, J. Bomani, H. Matsunaga, and T. Yokoyama, "Preparation of porous resin loaded with crystalline hydrous zirconium oxide and its application to the removal of arsenic," Reactive and functional Polymers, vol. 43, no. 1-2, pp. 65-172, 2000.

[6] P. Ratna Kumar, S. Chaudhari, K. Khilar, and S. Mahajan. "Removal of arsenic from water by electrocoagulation," Chemosphere, vol. 55, no. 9, pp. 1245-1252, 2004.

[7] M. Mureseanu, N. Cioatera, I. Trandafir, I .Georgescu, and F. Fajula, "Selective $\mathrm{Cu}^{2+}$ adsorption and recovery from contaminated water using mesoporous hybrid silica bio-adsorbents," Micropor Mesopor Mat., vol. 146, pp. 141-150, 2011.

[8] S. Rengaraj, K. Yeon, and S. Moon. "Removal of chromium from water and wastewater by ion exchange resins," J. Hazard. Mater., vol. 87, no. 1-3, pp. 273-287, 2001.

[9] X. D. Xin, W. Si, Z. X. Yao, R. Feng, B. Du, L. G. Yan et al. "Adsorption of benzoic acid from aqueous solution by three kinds of modified bentonites," J. Colloid. Interf. Sci., vol. 359, pp. 499-504, 2011.

[10] D. S. Chen, F. Yang, F. Pan, Q. Zhou, W. B. Yang, and A. M. Li, "Preparation of magnetic anion exchange resin and their adsorption kinetic behavior of reactive blue," Chin. Chem. Lett., vol. 22, no. 9, pp. 1901-1904, 2011.

[11] A. Ramesh, H. Hasegawa, W. Sugumoto, T. Maki, and K. Ueda. "Adsorption of gold (III), platinum (IV) and palladium (II) onto glycine modified cross linked chitosan resin," Biores. Techn., vol. 99 no. 9, pp. 3801-3809, 2008.

[12] K. A. Kraus, D. C. Michelson, and F. Nelson. "Desorption of negatively charged complexes by cation exchangers," Am. Chem. Soc., vol. 81, no.13, pp. 3204-3207, 1959.
[13] C. C. Zhang, X. Li, and J. X. Pang, "Synthesis and adsorption properties of magnetic resin microbeads with amine and mercaptan as chelating groups," J. Appl. Polym. Sci., vol. 82, no. 7, pp. 1587-1592, 2001.

[14] L. Tamayo-Rivera, R. Rangel-Rojo, Y. Mao, and W. H. Waston, "Ultra fast third-order non-linear response of amino-triazole donor-acceptor derivatives by optical Kerr effect," Opt. Commun., vol. 281, pp. 5239-5243, 2008.

[15] M. Takeuchi, T. Mizuno, S. Shinkai, S. Shirakami, and T. Itoh, "Chirality sensing of saccharides using a boronic acid-appended chiral ferrocene derivative," Tetrahedron-Asymmetr., vol. 11, pp. 3311-3322, 2000.

[16] C. Grogger, H. Fallmann, G. Fürpa $\beta$, H. Stüger, and G. Kickelbick, "The $\left[\mathrm{Cp}(\mathrm{CO})_{2} \mathrm{Fe}\right](\mathrm{Fp})$ group as a donor in donor/acceptor substituted disilanes: synthesis, structure and electronic properties of Fp- $\mathrm{Si}_{2} \mathrm{Me}_{4}-\mathrm{C}_{6} \mathrm{H}_{4} \mathrm{CH}=\mathrm{C}(\mathrm{CN})_{2}$," J. Organomet. Chem., vol. 665, pp. 186-195, 2003.

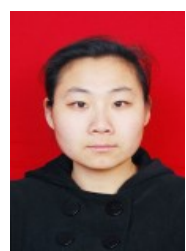

Qian Wang was born in February, 1985. She graduated from Qingdao University of Science and Technology in 2008. She is now for her Doctoral candidate in Kunming University of Science and Technology, Faculty of Environmental Science and Engineering. Majored in wastewater treatment.

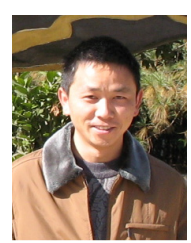

Senlin Tian was born in April 1975. He is the Professor in Faculty of Environmental Science and Engineering, Kunming University of Science and Technology. He gained the doctor degree of Environmental Science from Zhejiang University in 2004. And he majored in Air pollution and control and wastewater treatment.

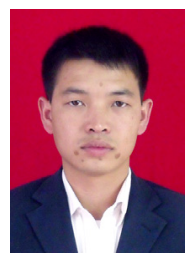

Zongliang He was born on December 1985. He gained the Master's degree of Environmental Engineering from Kunming University of Science and Technology. He is now working in Yunnan Soild Waste Management Center and majored in wastewater treatment. 